\title{
Key Strategies in Undertaking International Construction Project: Contractors' Perspective
}

\author{
Norliana Sarpin ${ }^{1, *}$, Chia Yi Ling ${ }^{1}$, Narimah Kasim ${ }^{1}$, Hamidun Mohd Noh ${ }^{1}$, Roshartini Omar ${ }^{1}$ and Rozlin Zainal ${ }^{1}$ \\ ${ }^{1}$ Department of Construction Management, Faculty of Technology Management and Business, Universiti Tun Hussein Onn Malaysia, \\ Parit Raja, Batu Pahat, Johor, Malaysia.
}

\begin{abstract}
The pressures of internationalisation have generated a high competitive market on Malaysian construction industry. However, the competitive and saturated of domestic market has driven many Malaysian contractor to undertake international projects. Without any denial, participation in international projects is a challenging task. It requires Malaysian contractors to develop strategy to enable them to operate successfully abroad. Therefore, the objectives of this research is to examine the key challenges for Malaysian contractors to undertake international construction projects thus identify strategies for Malaysian contractors to undertake international construction projects. To achieve the objectives of this research, quantitative method were adopted by using questionnaires. Questionnaire were distributed to participants from well experienced management team of G6 and G7 companies that have vast involvement in international projects. The findings of this research revealed that skilled worker shortage, high cost of financing of international project and limited experience with similar projects are the top three key challenges encountered by the Malaysian contractors in international construction project. The research identifies risk management and forming joint venture are the key strategies for Malaysian contractor to undertake international projects. In conclusion, this research can assist Malaysian contractor who wish to embark in international projects in supporting the current Construction Industry Transformation Programme (CITP) and the $4^{\text {th }}$ Industrial Revolution in construction industry.
\end{abstract}

\section{Introduction}

Construction industry has become more competitive in 21 st century, thus, there was a trend of internationalisation for Malaysian contractors to expand their business at outside of Malaysia in order to ensure their viability and long term survival in international market [1]. Although international construction project provides opportunities for Malaysian contractor, however, there was not only complex risk, but also uncertainties and challenges when Malaysian contractor accepting and contracting a project from outside of homeland [2]. Mostly, this is due to lack of international construction experiences and business operating environmental information [3].Without any denial, today's international construction is more complicated than ever [4]. Being a young player in international projects, a long gestation period is needed to cultivate the Malaysian contractor to emulate the well-known giants. Therefore, in order to compete well in the international market, there is a need to deep and core understanding on unique strategies to integrate all the challenges faced by Malaysian contractors.

According to [5], international construction project undertaken by Malaysian contractor sharply decline over the past decade. Furthermore, the number of Malaysian contractor involved in international project is relatively small [6]. Thus, there are obviously more challenges for international projects as compared to local project due to variety of difficulties [7].

As a preliminary study stated that majority of Malaysian contractor were reluctant and not interested to contribute international project due to high uncertainty from political risk and insufficient financial resources [8]. Besides that, according to [9], the main barriers for Malaysian construction companies to entry international market were lack of finance and insufficient information to access market. For instance, Malaysian contractors encountered inadequate financial margins in Gulf projects due to they were inexperienced and novice in the region thus winning the contract with a lowest bidder [2]. Therefore, there is a need for this research to identify the key challenges for Malaysian contractors to undertake international projects.

Furthermore, it is critical for Malaysian contractors to develop strategies in order to cope with the uncertainties, threats and then take advantages of the opportunities from internationalisation [8]. Therefore, this research attempt to identify suitable strategies for Malaysian contractor to undertake international projects.

* Corresponding author: norliana@uthm.edu.my 


\section{Literature review}

\subsection{Internationalisation of construction industry}

The internationalisation of construction firms is expanding of economic activities dramatically across national country's border [10]. According to [4], with the increased of project scope, more complicated construction projects are being procured and increased of modern industrialised countries has created a platform for international construction.

For example, Malaysian construction companies already ventured in ASEAN country such as Singapore, Indonesia, Cambodia and non-ASEAN such as Saudi, Dubai, the United State and Australia. Thus, going international can be defined as a market entry process through a construction firm which moves their operation solely from its local construction project to international construction projects [11].

Construction project is defined as wide divergence of project sites planning from the beginning to the end of building construction in between time, cost and quality as well as construction techniques [12]. However, international construction project can be defined as 'inter cultural' projects that have a number of difficulties precisely due to involve many different international companies or the employer, contractor and consultant are not come from same nationality and at least one of them is working outside of home country [13].

By taking advantages of international construction project opportunities, this allows Malaysian construction industry to reduce effects of domestic market condition and have better control over its own development [1]. However, risks are always accompanied by opportunities. Despite the opportunities that international projects offers, the contractors faced with various challenges when moving into international [14].

Contractors are one of the major players in construction industry and is expected to complete a project on time, within budgeted cost and desired quality level [15]. For international contractor, [16] has introduced its International Registered Contractor qualification criteria for Malaysian contractor as follow:

I. Registered with CIDB for not less than 3 years under active status

II. Proven track record in at least one completed project either local or overseas in the related field.

III. ISO9001:2008 certified.

\subsection{Challenges faced by contractor in International Construction Positioning}

Several reviews on previous studies and researches on international construction project had indicated the challenges that might be occurred when Malaysian contractor undertaking international project as shown in Table 1.
Table 1. Challenges in undertaking international construction projects

\begin{tabular}{|c|c|c|}
\hline Author, Year & & Challenges \\
\hline \multirow{2}{*}[17]{} & i. & Poor site management \\
\hline & ii. & Inadequate contractor experiences \\
\hline \multirow{5}{*}{ [1] } & i. & $\begin{array}{l}\text { Construction-related (Inadequate } \\
\text { of raw material, equipment and } \\
\text { tool shortage) }\end{array}$ \\
\hline & ii. & $\begin{array}{l}\text { Organisational (Incorrect planning, } \\
\text { Labour shortage, Training) }\end{array}$ \\
\hline & iii. & Environment (Unknown condition) \\
\hline & iv. & Political (Government policies) \\
\hline & $\mathrm{v}$. & $\begin{array}{l}\text { Legal (Lack of local construction } \\
\text { law) }\end{array}$ \\
\hline \multirow{4}{*}[18]{} & i. & Weak financing capacity \\
\hline & ii. & $\begin{array}{l}\text { Lack of familiarity of local system } \\
\text {,style and knowledge }\end{array}$ \\
\hline & iii. & Language barrier \\
\hline & iv. & Lack of coordination (Dispute) \\
\hline \multirow[b]{2}{*}[2]{} & i. & Financial (Interest rate) \\
\hline & ii. & $\begin{array}{l}\text { Economic (Price fluctuation, } \\
\text { exchange rate, inflation) }\end{array}$ \\
\hline \multirow{3}{*}[19]{} & i. & $\begin{array}{l}\text { Different construction code (Raw } \\
\text { material production) }\end{array}$ \\
\hline & ii. & Local requirement (Seismic load) \\
\hline & iii. & Different negotiation style \\
\hline \multirow[b]{2}{*}{ [3] } & i. & Change in law and contract \\
\hline & ii. & $\begin{array}{l}\text { Financial risk (Currency, Bank } \\
\text { loan) }\end{array}$ \\
\hline \multirow{4}{*}[20]{} & i. & $\begin{array}{l}\text { Natural challenges(Weather and } \\
\text { geological system) }\end{array}$ \\
\hline & & $\begin{array}{l}\text { Contractual challenges(Building } \\
\text { procurement, Safety measures) }\end{array}$ \\
\hline & iii. & Political challenges (War) \\
\hline & & $\begin{array}{l}\text { Cultural challenges(Different in } \\
\text { religion, Culture) }\end{array}$ \\
\hline
\end{tabular}

\subsection{Strategies in undertaking international construction projects}

Previous studies have identified a few strategies in undertaking international projects as shown in Table 2.

Table 2. Strategies in undertaking international projects

\begin{tabular}{|c|c|c|}
\hline Strategies & Items & $\begin{array}{l}\text { Author, } \\
\text { Year }\end{array}$ \\
\hline $\begin{array}{l}\text { Site } \\
\text { Management }\end{array}$ & $\begin{array}{l}\text { Efficient } \\
\text { management team to } \\
\text { gain trust }\end{array}$ & [9] \\
\hline \multirow{2}{*}{$\begin{array}{l}\text { Market } \\
\text { Entry } \\
\text { Strategy }\end{array}$} & $\begin{array}{l}\text { Market } \\
\text { decision }\end{array}$ & \multirow[b]{2}{*}{ [21] } \\
\hline & $\begin{array}{l}\text { Control system to } \\
\text { monitor performance }\end{array}$ & \\
\hline
\end{tabular}




\begin{tabular}{|c|c|c|}
\hline & $\begin{array}{l}\text { Construction joint } \\
\text { venture with local firm }\end{array}$ & {$[22]$} \\
\hline & $\begin{array}{l}\text { International Joint } \\
\text { Venture }\end{array}$ & {$[23]$} \\
\hline & $\begin{array}{l}\text { Choose experience and } \\
\text { familiar partner }\end{array}$ & {$[3]$} \\
\hline \multirow{2}{*}{$\begin{array}{l}\text { Control } \\
\& \text { Risk } \\
\text { Management }\end{array}$} & Risk reduction & \multirow{2}{*}{ 13] } \\
\hline & Risk mitigation plan & \\
\hline $\begin{array}{ll}\text { Joint } & \text { Venture } \\
\& & \text { Partner } \\
\text { Selection }\end{array}$ & $\begin{array}{l}\text { Ability, experience, } \\
\text { skills, financial ability, } \\
\text { willingness, spoken } \\
\text { language, track record, } \\
\text { JV experiences, mutual } \\
\text { understanding }\end{array}$ & 24] \\
\hline $\begin{array}{l}\text { Market } \\
\text { entry } \\
\text { decision }\end{array}$ & $\begin{array}{l}\text { Strategic alliance, local } \\
\text { agent, licensing, joint } \\
\text { venture branch office, } \\
\text { BOT }\end{array}$ & {$[25]$} \\
\hline \multirow{2}{*}{$\begin{array}{l}\text { Financial \& } \\
\text { Contractual } \\
\text { Management }\end{array}$} & $\begin{array}{ll}\text { Financial } & \text { resource } \\
\text { allocation } & \end{array}$ & \multirow{2}{*}[26]{} \\
\hline & Insurance Policies & \\
\hline
\end{tabular}

\section{Research methodology}

Methodology is a systematic, theoretical approach used to collect data and data analysis used to achieve particular objectives of a research. This paper used a quantitative approach to carry out in collecting data from targeted sample group by using questionnaires. This approach is used to examine and identify 'what' the challenges and strategies for Malaysian contractor in undertaking international project. Thus, this research presents the numerical data from questionnaires and the data was analyse quantitatively using Statistical Package for the Social Science (SPSS).

Sampling frame of this research was the main contractors from Malaysia that undertaken international construction project at outside of Malaysia and registered as G6 and G7 companies under CIDB. The respondents were well-experienced top and senior management level employees in the organisation such as project manager, site manager and senior manager. Thus, the targeted population was a list of 112 Malaysian contractor companies awarded to CIDB international construction projects. A total of 86 respondents were chosen from the targeted population of CIDB International Project Database according to [27].

The instrument used for gathering data was a questionnaire that comprises four sections. The first section was correspondent and company information, the second section was international construction project information, the third section was the challenges of international construction project while last section is strategies of international construction project. The measurement of items in third section is using a fivepoint Likert Scales which rank from $1=$ Not critical until $5=$ Extremely critical, whereas measurement for forth section is using five-point Likert scale which rank from $1=$ Strongly disagree to $=$ Strongly agree. Respondents able to indicate the degree of influences and level of their agreement by using five-point Likert Scale [28].
Data collected was analysed by using SPSS version 22.0. SPSS able to help researchers to manage, present and analyse large number of data into form of table and graphical chart and determine mean of the data collected. Thus, the results of this research were analysed and summarized by using descriptive analysis [29]. Descriptive analysis was used to describe the data and phenomenon being studied so that it is easier to understand.

\section{Results and discussions}

\subsection{Respondent and company background}

The items that are being analysed were company grade, designation of respondent, respondent working experience in construction industry, duration of company operate in international construction project, and international project information based on region and project type as shown in Table 3. The result shows that the respondents for this research were key players in international project with various roles and responsibilities, held managerial positions and have vast experience in construction industry.

Table 3. Respondent background

\begin{tabular}{|c|c|c|}
\hline \multicolumn{2}{|c|}{ Item } & Percentage $(\%)$ \\
\hline \multirow[t]{2}{*}{ Company's grade } & G6 & 40 \\
\hline & G7 & 60 \\
\hline \multirow{3}{*}{$\begin{array}{l}\text { Respondent's } \\
\text { designation }\end{array}$} & Project Director & 13 \\
\hline & Manager & 67 \\
\hline & Others & 20 \\
\hline \multirow{3}{*}{$\begin{array}{l}\text { Industrial } \\
\text { experience }\end{array}$} & 1 to 10 years & 38 \\
\hline & 11 to 20 years & 42 \\
\hline & More than 20 years & 20 \\
\hline \multirow{3}{*}{$\begin{array}{l}\text { Years of } \\
\text { experience in } \\
\text { international } \\
\text { project }\end{array}$} & 1 to 5 years & 45 \\
\hline & 6 to 10 years & 35 \\
\hline & 11 to 15 years & 20 \\
\hline \multirow{5}{*}{$\begin{array}{l}\text { Region of } \\
\text { international } \\
\text { project }\end{array}$} & Middle East & 27 \\
\hline & Africa & 10 \\
\hline & Asean & 50 \\
\hline & Europe & 3 \\
\hline & Other & 10 \\
\hline \multirow{7}{*}{$\begin{array}{l}\text { Type of } \\
\text { international } \\
\text { construction } \\
\text { project }\end{array}$} & Industrial building & 13 \\
\hline & Heavy/Highway & 32 \\
\hline & $M \& E$ & 10 \\
\hline & Residential building & 2 \\
\hline & Commercial building & 28 \\
\hline & Oil and Gas & 13 \\
\hline & Others & 2 \\
\hline
\end{tabular}

\subsection{Challenges in Undertaking International Construction Project}

Table 4 shows the findings of questionnaire survey regarding key challenges in undertaking international construction projects. Skilled worker shortage was the most challenging factor with mean score of 4.23. Followed by high cost of financing for international 
project with mean score of 4.20 . The third challenging factor was limited experience with similar project which indicates 4.18 mean score.

Table 4. Key challenges in undertaking international construction project

\begin{tabular}{|l|l|l|l|}
\hline Rank & Challenges & Mean & Category \\
\hline 1 & $\begin{array}{l}\text { Skilled Worker } \\
\text { Shortage }\end{array}$ & 4.23 & Human Resource \\
\hline 2 & $\begin{array}{l}\text { High cost of } \\
\text { financing for } \\
\text { international project }\end{array}$ & 4.20 & $\begin{array}{l}\text { Financial and } \\
\text { economic }\end{array}$ \\
\hline 3 & $\begin{array}{l}\text { Limited experience } \\
\text { with similar project }\end{array}$ & 4.18 & $\begin{array}{l}\text { Construction } \\
\text { related }\end{array}$ \\
\hline
\end{tabular}

Based on the finding of the questionnaire survey, the results demonstrated that skilled worker shortage in category of human resources is the most critical challenges faced by Malaysian contractors to undertake international project. Findings of [30] supported this where according to them, skilled labour shortage in construction industry have become worldwide issues which including United States, United Kingdom, Malaysia, Bahamas, India and also Canada. This is because majority of labours has been outsource from Bangladesh, Indonesia and others countries. There are lack of participation from local professional people working in construction site due to high risk of working environment and poor image of industry [31].

Furthermore, high cost of financing of international project was the second critical challenges. The challenges in financial and economic are including high cost of financing for international project, price inflation of construction materials and currency. According to [2], it is noteworthy that international projects have a high risk of loss since it is complicated as compared to local projects. The high international project cost is due to unstable international transaction for example currency exchange, interest rate and inflation. For newbies in international projects, it was not denied that the economic aspect of company would be more difficult to invest in international project, this is due to the company do not have previous business dealing with the local bank and had no special loan package [32].

According to the respondents, construction related challenges was the third most critical challenges in undertaking international project. Among the challenges are limited experiences with similar project and lack of coordination between designers and contractor. International projects is usually considered as high risk project, mostly this is due to lack of international environmental information and international construction experiences. Therefore, it is difficult for new entrance to examine new challenges in a new environment. According to [2], Malaysian contractors who took international project at Gulf Construction were not returning high profit due to they were inexperienced and novice in the region.

\subsection{Strategies for Malaysian Contractors to Undertake International Construction Project}

Table 5 shows the average mean score of four categories of strategies for Malaysian contractors when undertaking international projects. The most recommended strategies with the highest average mean score shown in the table is control and risk management with the value of 4.35 , followed by strategy for entry mode at the second place with the value of 4.28. Strategy related to site management with mean score of 4.28 and the lowest rank is strategy related to financial and contractual management with average mean score value of 4.00 .

Table 5. Strategy for Malaysian contractors to undertake international projects

\begin{tabular}{|c|l|c|}
\hline Rank & Strategies & Average mean \\
\hline 1 & Control and risk management & 4.37 \\
\hline 2 & Strategy for entry mode & 4.28 \\
\hline 3 & $\begin{array}{l}\text { Strategy related to site } \\
\text { management }\end{array}$ & 4.27 \\
\hline 4 & $\begin{array}{l}\text { Strategy related to financial and } \\
\text { contractual management }\end{array}$ & 4.00 \\
\hline
\end{tabular}

Majority of respondents agree that the strategy for Malaysian contractors to undertake international projects is to control the risk for example transfer or share risk to client and stated in contract. Risk of international construction project can be addressed with risk transfer by contract and insurance. According to [33], most of the international construction contractors have their own adequate contractual strategies with respect to project delivery risk such as site conditions, contractual issues such as extensions of time, liquidated damage and cost overrun. The strategies to manage these risk are risk transfer and share risks, subcontractors are often the typical recipients of risk transfer and it is the strategy used to protect main contractor [13]. Besides that, the insurance is a risk response that very important in international construction project strategy for example political risk insurance in unstable countries. Political risk insurance has provides protection with respect to political violence and currency inconvertibility. Besides that, contractors who involved in international projects can consider the use of risk identification and assessment tool prepared by Constriction Industry Institute for example International Project Risk Assessment (IPRA). It can used to assist in identify different classes of potential risk for international project and minimise the unknown-unknown.

Instead of risk management, the research also revealed that most of the respondent agreed with strategy to form joint venture and partnership with local partner firm for Malaysian contractor to undertake international project as an entry mode strategies. In general, forming joint venture with local firm could provide useful information such as choosing familiar partner, appointing reliable subcontractors and obtaining the credit terms from familiar suppliers. According to [13], one of the strategy for international contractors is to reduce jurisdictional risk by forming joint venture with a 
local partner. This is due to local firm more familiar with local country condition, political system, procurement system, language, culture, and construction method [3]. For instance, international joint venture of Leed Engineering and Construction, Malaysia with John Holland, Australia at South Road Superway, Australia [22].

In addition, forming of joint venture can overcome the challenges faced by Malaysian contractors such as weak financial capability, lack of management skills and lack of equipment. In order to minimise the risk of joint venture, some of the critical joint venture factors and partner selection should be address and identified before making any joint venture agreement [3]. From the research, financial capability was the most important factor for joint venture selection. Financial stability is essential for a prospective partner that can minimise financial risk caused by delays in payments, currency fluctuation, inflation and delays caused by government approval [24].

\section{Conclusion}

International construction project provide many excellent opportunities for Malaysian contractor to cooperate with foreign contractor and thus achieving the Malaysia Government policy of becoming strong industrialised economy and modernised nation. However, there was a risk, uncertainty and challenges business when Malaysian contractor accepting and contracting a project from outside of homeland. From this study, the key challenges for Malaysian contractor to undertake international construction project are skilled worker shortage, high cost of financing of international project and limited experience with similar projects. However, a few strategies was highlighted to overcome these challenges are control and managing risk such as transfer or share risk to client and stated in contract and forming Joint Venture with local firm as a strategy of entry mode. The findings of this research could be implement in supporting the current internationalisation strategic thrust in Construction Industry Transformation Programme 2016-2020 (CITP) initiative in increasing productivity in construction as well as in the $4^{\text {th }}$ Industrial Revolution specific in the construction industry.

Authors wishing to acknowledge Ministry of Higher Education Malaysia for supporting this research under the Research Acculturation Grant Scheme (R061).

\section{References}

1. A. Alashwal, and K. Prizada, Venturing into international construction project: Malaysian Perspective. Global Journal of Business and Social Science Review. January-March 2015. 1(2): 616630 (2015).

2. S. C. Loo, \& H. Abdul-rahman, Malaysian Contractors in Gulf Construction: A Preliminary
Study on Financial and Economic Risks. IACSIT International Journal of Engineering and Technology, 4(4), pp437-441 (2012).

3. Z. Abu Bakar, Challenges face by Malaysian contractors in international ventures. Multiversity Terminology Malaysia: Master of Science (2008).

4. W. Lu, H. Li, L. Shen, \& T. Huang. Strengths, Weaknesses, Opportunities, and Threats Analysis of Chinese Construction Companies in the Global Market, Journal of Management in Engineering, vol 25, no. 4, pp. 166-176 (2009).

5. N. K. Mustaffa,. H. Adnan, \& M. Z. Zakaria, Entry strategies for Malaysian Construction Related Companies Going Abroad. Australian Journal of Basic and Applied Sciences. 2012. 6(6): 323-330 (2012)

6. I. H. Hasan, Malaysian contractor job overseas worth USD 25.2 billion. Kuwait News Agency (2008).

7. C. M. Mat Isa, H. M. Saman, \& C. N. Preece, Determining significant factors influencing Malaysian construction business performance in international markets. Journal of Construction in Developing Countries, 20(2): 1-23 (2015).

8. C. M. Mat Isa, H. Adnan, and I. R. Endut, Malaysian contractors' opinions towards international market expansion. In International Conference in the Built Environment in the 21st Century (ICiBE2006). Vol. 1. Kuala Lumpur, 13-15 June, 287- 298 (2006).

9. C. N. Preece, C. K. I. C. Ibrahim, C. M. Mat Isa, \& H. M. Saman, Development of entry location, entry timing and entry mode decision model for construction firms in international markets. Construction Management and Economics, 2015. College of Engineering, Abu Dhabi University, United Arab Emirates (2015),

10. R. Korsakienè, Internationalization of construction firms: what strategy do they follow?' Entrepreneurship and Sustainability Issues 1(2): 99107 (2013).

11. P. Wong. Winds of Change: Ensuring Malaysian Builders Win In the Global Race, Master Builder Association, Malaysia (2007).

12. W. S. Han, A. M. Yusof, S. Ismail, \& N. C. Aun. Reviewing the Notions of Construction Project Success. International Journal of Business and Management. Vol. 7, No. 1; pp 90-101 (2012).

13. S. Kerur, \& W. Marshall. Identifying and managing risk in international construction projects. International Review of Law (2012).

14. G. M. Gad. Effect of culture, risk, and trust on the selection of dispute resolution methods in international construction contracts. Iowa State University: Graduate Theses and Dissertations. (2012).

15. I. Abe, The impact of contractors' pre-qualification on construction project delivery in Nigeria. 
Engineering, Construction and Architectural Management.19(2): 159-172 (2012).

16. Construction Industry Development Board. Buku Keperluan dan Prosedur Pendaftaran Kontraktor. m.s 49. CIDB (2015)

17. N. A. Jatarona, A. M. Yusof, S. Ismail, \& C. C. Saar, Public construction projects performance in Malaysia, Journal of Southeast Asian Research, Vol. 2016 (2016), pp.1-7 (2016)

18. C. M. Mat Isa, H. M. Saman, \& S. R. M. Nasir, (2013). Specific factors influencing market selection decision by Malaysian construction firms into international market. International Conference on Innovation, Management and Technology Research. 22-23 September 2013. Elsevier Ltd.: Social and Behavioral Science 129, 4-10 (2013)

19. C. F. Fernández, B. G. Cantó, \& C. G. Pastor, Internationalization of the construction sector: AEC application software. 1ST World Engineering Education Flash Week Lisbon (2011).

20. F. Y. Y. Ling, And L. Hoi, Risks faced by Singapore Firms when Undertaking Construction Projects in India. International Journal of Project Management 24. pp261-270 (2006)

21. C. M. Mat Isa, H. M. Saman, A, Jaapar. \& S. R. M.Nasir, Linking Entry Timing (ET) and Entry Mode (EM) Decisions in International Market Expansion by Malaysian Construction Firm: Toward the Development of ETEM Model. Proceedings of the 1st AAGBS International Conference on Business Management 2014 (AiCoBM 2014), pp.7992 (2014)

22. T. Ma, \& M. A. Voo, Comparative Study of Construction Joint Ventures in Australia and Malaysia. Construction Management \& Economics, School of NBE, University South Australia. (2014)

23. M. R. Stewart, \& R. D. Maughn, International Joint Ventures, A Practical Approach. The D logo, and Defining Success Together are registered trademarks of Davis Wright Tremaine LLP. (2011)

24. S. J. Minja, G. J. Kikwasi, and W. D. Thwala, $A$ study of joint venture formation between construction organization in Tanzania, Australasian Journal of Construction Economics and Building, Conference Series, 1 (2) 32-42 (2012)

25. C. Chen, \& J. I. Messner, Permanent versus mobile entry decisions in international construction markets: Influence of home country - and firmrelated factors. Journal of Management in Engineering, (January), 2-12 (2011)

26. C. Y. J. Cheah, \& M. J. Garvin, An open framework for corporate strategy in construction. Engineering, Construction and Architectural Management. Volume 11 Number 3, pp. 176-188. (2014)

27. R. V. Krejcie, \& D. W. Morgan, Determining sample size for research. Educational and Psychological Measurement. pp. 607-610 (1970)
28. C. R. Kothari, Research Methodology Methods and Techniques (Second Revised Edition). New Age International Publishers. pp 85. (2004).

29. W.L. Neuman, Basics of Social Research: Qualitative and Quantitative Approaches. Boston: Pearson. (2012)

30. S. B. A, Zaki, S. F. Mohamed, \& Z. M Yusof,. Construction Skilled Labour Shortage - The Challenges in Malaysian Construction Sector. International Journal of Sustainable Development, Vol. 4, No. 5, pp. 99-108 (2012).

31. ILO. The Construction Industry in The Twenty First Century: Its Image, Employment Prospects and Skill Requirements, Report For Discussion at the Tripartite Meeting on Construction Industry in The Twenty First Century: Its Image, Employment Prospects and Skill Requirements. (2001).

32. F. Y. Y. Ling, And L. Hoi, Risks faced by Singapore Firms when Undertaking Construction Projects in India. International Journal of Project Management 24. pp261-270 (2006).

33. J. Walewski, E, Gibson. and E, Vines. Risk Identification and Assessment for International Construction Projects. ICEC International Cost Management Journal Ljubljana, Slovenia (2012) 